\title{
Nigerian Experience VS. Biafran Experience: the Politics of Experience in Chinua Achebe and Chimananda Adichie's Novels
}

\author{
Jun $\mathrm{Li}$ \\ School of Foreign Languages \\ Luoyang Normal University \\ Luoyang, China
}

\begin{abstract}
Chinua Achebe and Chimananda Adichie are both Nigerian writers who gain world fames from their realist novels on Nigerian society. To some degree, Adichie is the successor to Achebe, not only because they share the same origin of Ibo culture, but also for their epic novels present the society of Nigeria and the images of Africans in the English world. However, they focus on different African experiences. The subtle politics of experience can be explored through the identity of their country: Achebe emphasizes Nigerian experience in his novels while Adichie insists on her Biafran experience.
\end{abstract}

Keywords-Chinua Achebe; Chimananda Adichie; Nigerian experience; Biafran experience

\section{INTRODUCTION}

Chinua Achebe and Chimananda Adichie are both Nigerian writers who gain world fames from their realist novels on Nigerian society. Achebe, as "the father of African literature in English," has shaped the world's understanding of Africa and its literature with his most widely read novels. Adichie, a young female novelist, also wins the international reception in English. Her Half of a Yellow Sun received the 2007 Orange Prize for Fiction and was listed among the New York Times's "100 Most Notable Books of the year." Even Achebe praised her as "a new writer endowed with the gift of ancient storytellers," who has taken "on the intimidating horror of Nigeria's civil war." (Chinua Achebe at 82: "We Remember Differently") To some degree, Adichie is the successor to Achebe, not only because they share the same origin of Ibo culture, but also for their epic novels present the society of Nigeria and the images of Africans in the English world. However, they focus on different African experiences. The subtle politics of experience can be explored through the identity of their country: Achebe emphasizes Nigerian experience in his novels while Adichie insists on her Biafran experience.

Igbo, Hausa and Yoruba are the main ethnic communities in Nigeria. Before Nigeria was founded by the white colonizers, the three communities have settled in the same land and developed different customs. In fact, "Nigeria" itself is the construction of the colonizers. Accepting "Nigeria" as their own motherland means to give up some disputes and admit to the colonized distribution of power This fact proves to be tough. Historical disputes and the intentional injustice from the whites intensify the opposition among Hausa, Yoruba and Igbo. So it is hard to acquire a balance between the national identity as a Nigerian and the ethnic identity as an Ibo, Hausa or Yoruba. For Achebe, he is proud of being a Nigerian and wants to assure the Nigerian nationality. He even denied the relation between English and colonization, for "We chose English not because the British desired it but because having tacitly accepted the new nationalities into which colonialism had grouped us, we needed its language to transact our business, including the business of overthrowing colonialism itself in the fullness of time." (The African Writer and the English Language) Achebe is more like a cosmopolitan who desires African identity in front of the international world. For him, the description of Ibo culture and society is a better illustration of Nigerian identity. But for Adichie, Achebe's world is also "incredibly exotic" (Adichie 42) which brings a wrong impression for westerners. She realizes that perhaps Achebe's Things Fall Apart plays a role in this impression: the book set in the Nigeria of a hundred years ago cannot tell the norm in contemporary life. (Adichie 43) Adichie prefers to writing the Ibo society in the civil war (also the NigerianBiafran War) when her people suffered the massacre and the delusion of the Republic of Biafra. The identity of Ibo is her emphasis

\section{NIGERIAN EXPERIENCE IN ACHEBE's NOVELS}

In Achebe's novels, epic narratives always lead to the identity of Nigerian or African. All the characters in Achebe's novels belong to Nigerian people, namely the nationalist identity of Nigerians. Okonkwo in Things Fall Apart is taken as a kind of Aristotelian tragic hero, an example of African glory and failure during the process of colonization. Odili in A Man of The People is in political struggle with the corrupted Chief Nanga and his political endeavor seems similar to the western politics of election without relation to ethnic disputes. Chris and Ikem in Anthills of the Savannah are fighting against the dictator Sam who was their friend in the youth, with little implication to their ethnic identity. Not only the characters are full of the 
same identity, the narratives are also mingled with poems of praise to Nigeria and Africa. In No Longer at Ease, a patriotic poem about Nigeria written by the protagonist Obi is referred to the Nigerian dream of the educated elites:

God bless our noble fatherland,

Great land of sunshine bright,

Where brave men chose the way of peace,

To win their freedom fight.

May we preserve our purity,

Our zest for life and jollity.

God bless our noble countrymen,

And women everywhere.

Teach them to walk in unity

To build our nation dear;

Forgetting region, tribe or speech,

But caring always each for each. (78)

Obi names this poem "Nigeria" in London two years before he returns to his homeland. The pride and love for Nigeria is clearly shown in this poem and his other nostalgic poems about motherland. To build their nation of Nigeria asks for the unity and the whole identity of Nigerian people, especially the educated elites who should forget region, tribe or speech. In fact, this pride and faith can function to the African identity similarly.

African identity, anti-Eurocentrism are both the themes of Chinua Achebe's novels. Things Fall Apart, his first novel, was described by himself as "an act of atonement, the homage of a prodigal son." He created the African heroes, intellectuals, officials and such characters to tell the "real" Nigerian stories in the perspective of Nigerian characters. His efforts are taken as a construction of African identity and a denial to Eurocentrism. However, his discourse does not succeed, but merely creates a real effect. The effacing narrative in No Longer at Ease can be a best illustration.

Chinua Achebe's No Longer at Ease, as his second novel, turns to the turbulent society of Nigeria before the Independence from European colonizer. Different from the epic description of Ibo hero and community in Things Fall Apart, it penetrates by a narration of individual tragedy in a realist way while in effect creates a national allegory of Nigeria. Not only for Obi, the protagonist of this novel, but also for the Nigerian society, they are no longer at ease. Obi, the protagonist, whose name originated from "the mind at last is at rest" in Ibo, was finally absent from this expectation. He got the high education aboard and accepted a "European post" (8) in the capital which assured him to be a middle class in Nigerian society before the Independence. However, he lost the passion and faith in his Nigerian dream due to the materialist pressure and the narrow tribal culture. He surrendered to corruption prevailing in the official circles without any resistance to car, apartment, steward, and other signs of power and pride. He departed from his girlfriend
Clara for she came from an Osu family, the cursed and distorted community in Ibo. All the dreams about Nigeria and himself turned to an illusion for his individual tragedy.

Obi's tragedy is not merely his own tragedy but a symbolization of the falling of Nigerian society before the Independence. It is the national allegory alluding to the corruption and failure in Nigerian modernization and independence. First, Obi, as a representative of new blood in Nigerian politics, lost his conscience and faith in the construction of this new country little by little. The disappointment of this middle class is not directly from the colonized reality but from local vices such as corruption and tribal pride which can be taken as part of culture. Bribery becomes the rule in public life, even when a girl voluntarily chooses to offer sex to the official in the Scholarship Board. Obi's education provider, the Umuofia Progressive Union (UPU), even agreed to support the bribery for a post in government out of their tribal interests. This support is called "an investment which must yield heavy dividends."(26) Second, the nonfeasance of the Nigerian elites on national issues deprives the foundation of Nigerian society. Almost all the educated Nigerian are concerned with their treatment, vacations, and pride in "European post." Just as Mr. Green said, they got education "[T]o get as much as they can for themselves and their family. Not the least bit interested in the millions of their countrymen who die every day from hunger and disease. "(89) So even a white colonizer (Mr. Green) can feel sorry for Nigeria and blame the elites for their omission of duty. It is really a shame for the responsibility of Nigerian political elites.

More importantly, in No Longer at Ease, the narration and perspective of Obi prevail over the effacing narrative towards European colonizers. The third-person narrator tells Obi's corruption with a center only on Obi's story. The European colonizers, for Obi and his people, are totally "others," a kind of unavoidable reality and authority. Few characters of colonizers are depicted and analyzed. The only one further portrayed is Mr. Green, Obi's leader. Mr. Green is depicted as a new image of colonizer: hard-working for the sake of Nigeria out of his own responsibility, rigidly criticizing at Nigerians' incapability but sympathy for their suffering. "Here was a man who did not believe in a country, and yet worked so hard for it." But the tone of the narrator proves that $\mathrm{Mr}$. Green is let down by the disappointing moves of educated Africans. It seems "the tragedy of the Greens of this century":

He must have come originally with an ideal---to bring light to the heart of darkness, to tribal head-hunters performing weird ceremonies and unspeakable rites. But when he arrived, Africa played him false. Where was his beloved bush full of human sacrifice? There was St George horsed and caparisoned, but where was the dragon? In 1900 Mr. Green might have ranked among the great missionaries; in 1935 he would have made do with slapping headmasters in the presence of their pupils; but in 1957 he could curse and swear. (81)

So the narrator distributes the disappointment of $\mathrm{Mr}$ Green to the result of the era in which the Nigerians are 
corrupt, no longer as he thought. The main criticism focuses on the educated Nigerians, except for European colonizers. This transformation reflects Achebe's subtle attitude: a strategy of cultural politics to arouse westerners' interests on African problem with his mild position.

Achebe uses his Nigerian novels to develop the subjectivity of his people and to resist the unreal portrayal of the black by the white. He criticized Joseph Conrad as "a thoroughgoing racist" in the 1975 lecture "An Image of Africa: Racism in Conrad's 'Heart of Darkness'." His Nigerian writing aims to build an example for African literature. This contributes partly to the reason why he is called "the father of African literature in English." He has a pan-African ideology that "consecrates the idea of Africa as a unified 'nation,' irrespective of the distinct territoriality that it assumed later with the political reality of the various spheres of European influence" (Nwakanma 3). The ideology is closely related to nationalism. With nationalism, the African identity as a whole can impress the whites that they are out of the control of their colonies. As Irele notes, "[I]f nationalism in Africa and the Third World aspires in each domain of its expression toward a re-integration of the communal past within the collective awareness, it has perforce to acknowledge an epochal break with the past provoked by the colonial, western incursion." (75). So Nigerian national literature participates in African literature and flows from this "historical consciousness inherent in nationalism" (Nwakanma 3). This can easily explain why Achebe's novels transcend the regional, tribal perception to set an African instance of the political irony and allegory in a general extent. And it can also tell why Achebe effaces his Biafran experience in the political novels with less narrative about the massacre of his Ibo people.

\section{BIAFRAN EXPERIENCE IN ADICHIE'S NARRATION}

As a postcolonial novelist, Adichie values her Igbo identity in the expression of her Biafran experience. In Half of a Yellow Sun, she deals the plot and narrative just as Margaret Mitchell did in Gone With the Wind. The narrators' perspectives are always in Biafran identity and the implied narrator (the second self of the author) also contains the position of Ibo. The massacre toward Ibos is depicted in detail, including the brutal abuses, the ruthless slaughters, and cruel air raids. The death of civilians is not exaggerated with a portrayal of Ibos killed for their Igbo accent, and victims in the Republic of Biafra starving to death with the intentional blockade of food from the Hausa-dominated government. One horrible image is the woman caressing a calabash containing her daughter's head:

The woman with the calabash nudged her, then motioned to some other people close by.... Olanna looked into the bowl. She saw the little girl's head with the ashy-grey skin and plaited hair and rolled-back eyes and open mouth....Somebody screamed. The woman closed the calabash. 'Do you know,' she said, 'it took me so long to plait this hair? She had such thick hair,' (149)

This vivid description is hard to forget, arousing readers' imagination on the crime of war. Similar cruel details of war exist in this novel. So they are the different strategy of politics compared with the simple mention of killing twins in Igbo culture, the deliberate effacing of scenes of massacre and the tragic death of Ibo heroes in Achebe's novels. Meanwhile, all the characters are Ibos who can hardly admit they are Nigerians in front of tribal disputes and massacre. The war brings them only pains and daze loss in the faith that they are the people who participate in the construction of Nigeria. Ugwu, a houseboy, is innocently drawn to the war in which he suffers from the deaths but has to prove himself as a Biafran soldier by acts of sex violation. Odenigbo, Ugwu's Igbo master, entertains his colleagues in the Igbo college to discuss the political issues in Nigeria as an enthusiastic Biafran intellectual. After experiencing the massacre and the refuge, he lost his passion and faith in the war. Richard, a white writer and journalist, is involved in the war with his Biafran friends. He records the suffering of the Ibos but cannot get the reality published because the western world is looking for the tabloid sensationalism in the massacre and starvation without any concern for the Biafran people. For Adichie, the Biafran history is the most important part of Nigerian history which should not be forgotten for the sacrifice of Ibos.

Different from Achebe's ellipsis of direct blame on the white colonizers, Adichie exposes the crime of the whites on Nigeria by the exploration of the white journalist Richard. Richard has to experience the war with his Ibo friends, though his fist purpose is to study the arts in Nigeria. Seeing the massacre, the air raid, and the refugees, he turns to speak for the Biafran people in his news and book The World Was Silent When We Died. From "we" in the title of this book, Richard voluntarily identify with the Biafran people. In fact, he struggles to correct the westerners' stereotypes about Nigerian war and Igbo people in the book. He pinpoints that the western interference lies behind Nigerian turmoil and the interests of past colonizers are intertwined with tribal disputes in political powers. A book reflecting the reality of Biafran people by a white journalist proves to be the best way to resist the manipulation of the international public opinion from the western countries.

Adichie's rethinking of the importance of Biafran experience in Nigerian history is a try of multiple experience in postcolonial Nigeria. She was born after 1970 and never went through the Nigerian-Biafran War. But she is deeply impressed by family memories about that war, as she noted "we know of property lost, of relatives who never 'returned' from the north, of shadows that hung heavily over family stories. We inherited memory. And we have the privilege of distance that Achebe does not have." (Chinua Achebe at 82: "We Remember Differently") It is her generation to recall Biafran experience to correct the injustice toward Ibos and to explore the complexities of reality which still control Nigerian public since then. Without uncovering these historical veil, Ibos will never get out of marginalization for they still think they are a defeated people and indifferent to the hostility of "fear of Igbo domination" from other ethnic groups. Adichie once commented "We cannot deny ethnicity. It matters. But our ethnic and national identities should not be spoken of as though they were mutually exclusive; I am 
as much Igbo as I am Nigerian." (Chinua Achebe at 82: "We Remember Differently") Her Biafran experience confirms the diversity of Nigerian identity, just as her saying "The Nigerian stage is big enough. Chinua Achebe has told his story." (Chinua Achebe at 82: "We Remember Differently") However, both she and Achebe are English writers wellknown to the western readers. This fact cannot deny the consuming nature of their African experience. As Achebe's description of Igbo hero and culture aims to manifest Africa, Adichie's detailed portrayal of the Nigerian-Biafran War also objectively arouses the curiosity of the western readers though she purports to tell her own Biafran experience.

\section{CONCLUSION}

Though both Achebe and Adichie are Ibo, the notion of identity in their novels are different: Achebe's Ibo characters as archetypes of Nigerians to represent African heroes while Adichie's characters identified as Biafran elites representing only for Ibo. So Achebe emphasizes on Nigerian experience as a whole by an example of Ibo images and cultures while Adichie focuses on Biafran experience to show the suffering and faith of peace for Ibos in Nigeria.

\section{REFERENCES}

[1] Achebe, Chinua. No Longer at Ease. London: Penguin, 2010.

[2] Achebe, Chinua. "The African Writer and the English Language," London: Penguin, 2010.

[3] Adichie, Chimamanda Ngozi. "African 'Authenticity' and the Biafran Experience," Transition, 99 (2008): 42-53

[4] Adichie, Chimamanda Ngozi. Half of a Yellow Sun. Lagos: Farafina, 2006.

[5] Adichie, Chimamanda Ngozi. Half of a Yellow Sun. Shi Pingping trans. Nanjin: Yilin, 2010.

[6] Nwakanma, Obi. "Metonymic Eruptions: Igbo Novelists, the Narrative of the Nation, and New Developments in the Contemporary Nigerian Novel," Research in African Literatures, 39. 2 (2008): 1-14.

[7] Chimamanda Ngozi Adichie, Chinua Achebe at 82: "We Remember Differently"

[8] http://premiumtimesng.com/arts-entertainment/108378-chinuaachebe-at-82-we-remember-differently-by-chimamanda-ngoziadichie.html

[9] Chinua Achebe, The African Writer and the English Language

[10] http://www.google.com.hk/url?sa=t\&rct=j\&q=The $\% 20$ African $\% 20 \mathrm{~W}$ riter $\% 20$ and $\% 20$ the $\% 20$ English $\% 20$ Language \&source $=$ web \&cd $=1 \&$ ved $=0$ CCgQFjAA\&url= $\% 68 \% 74 \% 74 \% 70 \% 3 \mathrm{a} \% 2 \mathrm{f} \% 2 \mathrm{f} \% 63 \% 68 \% 69$ $\% 73 \% 6 \mathrm{e} \% 65 \% 6 \mathrm{c} \% 6 \mathrm{c} \% 2 \mathrm{e} \% 63 \% 6 \mathrm{f} \% 6 \mathrm{~d} \% 2 \mathrm{f} \% 41 \% 50 \% 45 \% 6 \mathrm{e} \% 67 \%$ $2 \mathrm{f} \% 42 \% 61 \% 63 \% 6 \mathrm{~b} \% 67 \% 72 \% 6 \mathrm{f} \% 75 \% 6 \mathrm{e} \% 64 \% 4 \mathrm{e} \% 6 \mathrm{f} \% 74 \% 65 \% 73$ $\% 2 \mathrm{f} \% 41 \% 63 \% 68 \% 65 \% 62 \% 65 \% 2 \mathrm{f} \% 74 \% 66 \% 61 \% 73 \% 75 \% 62 \% 61 \%$ $6 \mathrm{c} \% 74 \% 65 \% 72 \% 6 \mathrm{e} \% 2 \mathrm{e} \% 72 \% 74 \% 66 \&$ ei $=$ ckjNUv-

PH86QiAfFlIHgDQ\&usg=AFQjCNF3p6gHB9xME8LqiqkCalILCP9 $\mathrm{wAw} \& \mathrm{bvm}=\mathrm{bv} .58187178, \mathrm{~d} \cdot \mathrm{aGc} \& \mathrm{cad}=\mathrm{rjt}$ 